\title{
Steam Bioprocessing Philosophy of Cereals for Ruminants: Time for a New History
}

\author{
Akbar Nikkhah ${ }^{*}$ \\ Chief Highly Distinguished Professor, Department of Animal Sciences, University of Zanjan, Iran
}

"Corresponding author: Akbar Nikkhah, Chief Highly Distinguished Professor, Department of Animal Sciences, Faculty of Agricultural Sciences, University of Zanjan, Zanjan, Iran, Tel: +98-24-330-528-01; Fax: +98-24-330-532-02; E-mail: nikkhah@znu.ac.ir

Rec date: Sep 03, 2014, Acc date: Sep 03, 2014, Pub date: Sep 06, 2014

Copyright: (C) 2014 Nikkhah A. This is an open-access article distributed under the terms of the Creative Commons Attribution License, which permits unrestricted use, distribution, and reproduction in any medium, provided the original author and source are credited.

\section{Editorial}

This editorial concisely and elaborately describes and criticizes historical misuses of cereal grains in managing food-producing ruminants. The article also presents clear-cut philosophies for optimal utilization of cereal starch and protein by high-producing modern dairy and beef ruminants. Securing this knowledge is very crucial since mismanagement in feeding differently dry- and steam-processed cereal grains causes prolonged Subacute Rumen Acidosis (SARA), challenges immunity, reduces nutrient intake, and ruins farm economy [1].

Starch is the core storage carbohydrate in cereals. Starch is made of amylase and amylopectin. Amylose is a linear polymer of 1-4, Dglucose units, while is amylopectin a branched polymer with linear chains of D-glucose with a branch point in every 20-25 glucose units. Harder grains include corn and sorghum and softer grains usually refer to wheat, barley and oats. Harder grains typically have lower degradation rate and extent than softer grains, especially shortly after feed presentation. An optimal global processing philosophy for harder grains (e.g., corn and sorghum and some varieties of wheat and barley) is that steam-treatment should help starch granules timely swallow under moist heat to be fermented more effectively and synchronously in the rumen [2-4]. Thus, steam-processing is to increase rumen fermentation rate and extent to degrees within which nitrogen and energy supplies become optimally rapid and synchronous to augment microbial biomass. In softer grains such as barley and wheat, however, the processing philosophy is totally different. Despite increasing rumen fermentation rate and extent of corn and sorghum grains, steamprocessing aims to reduce and control starch degradation rate in toorapidly degradable barley and wheat grains [5].

For limited small intestinal capacity of starch assimilation, it has been aimed to optimize starch and energy use by shifting digestion site from the small intestine to the rumen [3]. Undoubtedly, in barley and wheat grains that are already overly rapidly fermentable, the goal must be to moderate rumen degradation rate to shorten periods of SARA (e.g., $<3$ h/d). Such different philosophies ought to be optimally appreciated by ruminant specialists and farm managers for rumen health, microbial efficiency and food production to be improved.

To state simply and globally, causing problems and searching for solutions is by all means unwise. With improved management, problems must be prevented or at the very least be maintained under timely control. Vainness in overfeeding cereal grains (i.e., $40-50 \%$ barley in dairy diet DM) will mean ingesting a minimum of $24-30 \%$ starch just coming from grains with ineffective fibers for rumen health $[6,7]$. Elongated SARA would, as a result, occur. Such an over modernization must be avoided in today's farm management [5].

It should be remembered that except for unique conditions, in standard nutrition programs, it is not feed or starch that pushes animal to produce, but it is rather ruminant physiology that drives responses to feeding management strategies. Continual contemplations are required for optimal cereal bioprocessing philosophies and techniques to be suitably acknowledged and practiced by modern and postmodern ruminant farmers. Of utmost importance is to cease ongoing through a mistaken history or overfeeding cereals blindly regardless of bioprocessing techniques aiming to maximize profits. The paramount is generating a new history that necessitates feeding optimal amount of cereal grains with right bioprocessing philosophy. This is the future in helping boost economy.

\section{Acknowledgments}

The Ministry of Science Research and Technology, and University of Zanjan, Iran, are thankfully acknowledged for supporting the author's global programs of improving science edification in the new millennium.

\section{References}

1. Nikkhah A (2012) Barley grain for ruminants: A global treasure or tragedy. J Anim Sci Biotechnol 3: 22.

2. Nikkhah A and Ghorbani GR (2003) Effects of dry and steam processing on in situ ruminal digestion kinetics of barley grain. Journal of Animal Science 81: 338 .

3. Huntington GB (1997) Starch utilization by ruminants: from basics to the bunk. J Anim Sci 75: 852-867.

4. Nikkhah A, Alikhani M, Amanlou H (2004) Effects of feeding ground or steam-flaked broom sorghum and ground barley on performance of dairy cows in midlactation. J Dairy Sci 87: 122-130.

5. Nikkhah A (2012) Barley grain for rumen and ruminants: overmodernized uses of an inimitable fuel. Journal of Animal Science and Biotechnology 3:22.

6. Silveira C, Oba M, Beauchemin KA, Helm J (2007) Effect of grains differing in expected ruminal fermentability on the productivity of lactating dairy cows. J Dairy Sci 90: 2852-2859.

7. Yang WZ, Beauchemin KA, Koenig KM, Rode LM (1997) Comparison of hull-less barley, barley, or corn for lactating cows: effects on extent of digestion and milk production. J Dairy Sci 80: 2475-2486. 